\title{
Wpływ nowelizacji dyrektywy 96/71/WE Parlamentu Furopejskiego i Rady z dnia 16 grudnia 1996 r. dotyczącej delegowania pracowników w ramach świadezenia usług na statut stosunku pracy
}

\begin{abstract}
The Directive (EU) 2018/957 of the European Parliament and of the Council of 28 June 2018 introduced several changes to the Directive 96/71/EC on the posting of workers in the framework of the provision of services, affecting the posted worker's employment relationships directly. Article 3(1) of the Directive 96/71/EC requires that an employer has to guarantee his workers posted to the Member State, the terms and conditions of employment, in matters listed in it, resulting from the law where the work is carried out, regardless of the law applicable to employment relationships. First of all, the Directive (EU) 2018/957 introduced the new concept of "remuneration" paid to the posted workers. Secondly, it extended the list of mattes in article 3(1) by adding point (h) - "the conditions of workers' accommodation where provided by the employer to workers away from their regular place of work" and point (i) - "allowances or reimbursement of expenditure to cover travel, board and lodging expenses for workers away from home for professional reasons." Finally, the Directive (EU) 2018/957 established the posting period, not clearly defined before, which should not last longer than 12 months (18 months when the service provider submits a motivated notification).

This paper analyses the main changes introduced by the Directive (EU) 2018/957 amending the Directive 96/71/EC in the employment relationship field.
\end{abstract}

a) Dr hab., prof. UŚ, Uniwersytet Śląski w Katowicach. 
Keywords: the posted workers, freedom to provide services, law applicable to the individual employment contracts, Rome I Regulation, Directive 96/71/EC, Directive (EU) $2018 / 957$

\section{Uwagi ogólne}

Wprowadzone dyrektywą Parlamentu Europejskiego i Rady (UE) 2018/957 z dnia 28 czerwca 2018 r. ${ }^{1}$ zmiany obowiązującej już od dwudziestu lat dyrektywy 96/71/WE Parlamentu Europejskiego i Rady z dnia 16 grudnia 1996 r. dotyczącej delegowania pracowników w ramach świadczenia usług ${ }^{2}$ odnoszą się do dwóch kwestii. Po pierwsze, w jeszcze większym zakresie nakładają na państwa członkowskie oraz pracodawców delegujących swoich pracowników poza państwo, w którym zwykle świadcza pracę, obowiązi o charakterze formalno-administracyjnym ${ }^{3}$, mające na celu „zwalczanie oszustw związanych z delegowaniem pracowników”4. Mimo bowiem niedawnego wprowadzenia do obrotu prawnego unormowań w tym zakresie, wynikających z dyrektywy Parlamentu Europejskiego i Rady 2014/67/UE z dnia 15 maja 2014 r. ${ }^{5}$, która miała doprowadzić ${ }^{6}$ do

${ }^{1}$ Dyrektywa Parlamentu Europejskiego i Rady (UE) 2018/957 z dnia 28 czerwca 2018 r. zmieniająca dyrektywę 96/71/WE dotycząca delegowania pracowników w ramach świadczenia usług. Dz.Urz. UE L nr 173 z dnia 9.07.2018, s. 16—24 [dalej: dyrektywa 2018/957].

${ }^{2}$ Dz.Urz. UE L nr 018 z dnia 21.01.1997, s. 1—6 [dalej: dyrektywa 96/71/WE].

${ }^{3} \mathrm{~W}$ tym zakresie zob. w szczególności P. Wąz: Zmiany $w$ zakresie delegowania pracowników do innego państwa celem świadczenia ustug od 30.7.2020 r. „Monitor Prawa Pracy" 2020, nr 10, s. 11.

${ }^{4}$ Cytat z motywu 26. dyrektywy 2018/957.

${ }^{5}$ Dyrektywa Parlamentu Europejskiego i Rady 2014/67/UE z dnia 15 maja 2014 r. w sprawie egzekwowania dyrektywy 96/71/WE dotyczacej delegowania pracowników w ramach świadczenia usług, zmieniająca rozporządzenie (UE) nr 1024/2012 w sprawie współpracy administracyjnej za pośrednictwem systemu wymiany informacji na rynku wewnętrznym („rozporządzenie w sprawie IMI”). Dz.Urz. UE L nr 159 z dnia 28.05.2014, s. 11-31 [dalej: dyrektywa 2014/67/UE].

${ }^{6}$ Na temat dyrektywy 2014/67/UE zob. szerzej P. Wą̇̇: Projekt dyrektywy w sprawie egzekwowania dyrektywy 96/71/WE dotyczqcej delegowania pracowników w ramach świadczenia usług. „Monitor Prawa Pracy” 2013, nr 9, s. 453-459; M. Wołoszyn- Juszczyk: Perspektywy delegowania pracowników polskich do krajów Unii Europejskiej. W: Studia z zakresu prawa pracy i polityki społecznej. Red. A.M. Świątkowski. Warszawa 2014, s. 363-370; P. Kwasiborski: Planowana rewizja dyrektywy 96/71/ WE $w$ świetle dotychczasowych uwarunkowań prawnych instytucji delegowania pracowników w Unii Europejskiej. „Europejski Przegląd Sądowy” 2016, nr 6, s. 13, 17. 
„zapobiegania nadużywania oraz obchodzenia obowiąujących przepisów przez przedsiębiorstwa korzystające z zapisanej w TFUE swobody świadczenia usług, lub z przepisów dyrektywy 96/71/WE w sposób nieodpowiedni bądź nieuczciwy, oraz unikania tych zjawisk i ich zwalczania"7, uznano, że wskazane cele mogą zostać osiagnięte jedynie przez stworzenie kolejnych „zrównoważonych ram dotyczących swobody świadczenia usług i ochrony pracowników delegowanych, które sa nie-

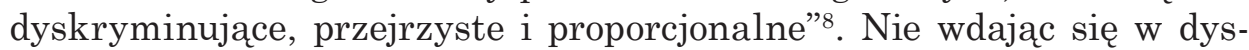
kusję, czy taki był rzeczywisty cel polityczny wprowadzanych zmian, czy też było nim zapewnienie ochrony wewnętrznych rynków pracy w państwach Unii Europejskiej sprzed poszerzenia w roku $2004^{9}$, warto skupić się w tym miejscu na wpływie dyrektywy 2018/957 na statut stosunku pracy. Dalsza ingerencja legis loci laboris w treść stosunku pracy pracowników delegowanych, kształtowaną co do zasady przez prawo dla niego właściwe, była bowiem drugim zamierzeniem autorów omawianej nowelizacji.

Zgodnie z założeniami, dyrektywa 96/71/WE miała zapewnić zrównoważenie sprzecznych interesów różnych podmiotów. Ochrona uzasadnionych praw pracowników, mających świadczyć pracę poza krajem, gdzie zwykle to czynilii ${ }^{10}$, nie mogła bowiem przekreślić traktatowej swobody świadczenia usług, gwarantującej równe warunki działania przedsiębiorców z różnych państw członkowskich ${ }^{11}$. Sposobem, jaki autorzy dyrektywy 96/71/WE przyjęli, by założenie to zrealizować, była prawna ingerencja w treść stosunku pracy łączącego usługodawcę wykonującego zamówienie w innym państwie członkowskim z jego pracownikiem, który w zwiazku z tym został delegowany do świadczenia pracy poza miejsce (państwo) zwykłego wykonywania swoich obowiązków ${ }^{12}$. Co do zasady,

${ }^{7}$ Cytat z motywu 7. dyrektywy 2014/67/UE.

8 Cytat z motywu 24. dyrektywy 2018/957.

${ }^{9}$ P. Kwasiborski: Planowana rewizja..., s. 21; L. Mitrus: Charakter prawny delegowania pracowników $w$ ramach swobody świadczenia ustug $w$ Unii Europejskiej. „Europejski Przegląd Sądowy” 2018, nr 6, s. 8, 10-11.

10 Jak wynika z motywu 4. dyrektywy 2018/957, stanowi ona odpowiedź na wyniki oceny efektów stosowania dyrektywy 96/71/WE w pierwotnej wersji w zakresie zapewnienia „właściwej równowagi między koniecznością wspierania swobody świadczenia usług i zapewnienia równych warunków działania z jednej strony a koniecznością ochrony praw pracowników delegowanych z drugiej”.

${ }^{11}$ M. Wołoszyn-Juszczyk: Perspektywy delegowania..., s. 357-359; M. Zachariasiewicz, w: „System Prawa Prywatnego”. T. 20B: Prawo prywatne międzynarodowe. Red. M. Pazdan. Warszawa 2015, s. 498, 500-501; S. de Carvalho: The revision of the Posting of Workers Directive and the freedom to provide services in EU: towards a dead end? „Juridical Tribune” 2018, vol. 8, s. 720.

12 S. de Carvalho: The revision of the Posting of Workers Directive..., s. 722-725. 
zgodnie z art. 8 ust. 2 rozporządzenia Rzym I' ${ }^{13}$ (a wcześniej art. 6 ust. 2 konwencji rzymskiej ${ }^{14}$ ), umowa o pracę podlega prawu państwa, w którym pracownik zazwyczaj ja świadczy. Najczęściej jest nim więc prawo państwa, z którego pochodzi usługodawca zatrudniający osoby wykonujace na jego rzecz pracę $e^{15}$. Jednakże $\mathrm{w}$ odniesieniu do enumeratywnie określonych w art. 3 dyrektywy 96/71/WE kwestii znajduje zastosowanie - niezależnie od tego, jakie prawo jest właściwe dla danego stosunku pracy - prawo kraju, do którego pracownik został delegowany.

Dyrektywa 96/71/WE w kluczowym dla ochrony pozycji prawnej pracowników delegowanych aspekcie posługuje się mechanizmem kolizyjnym ${ }^{16}$. Ma on za zadanie korygowanie statutu stosunku pracy wyznaczonego na podstawie reguł kolizyjnych wynikajacych z art. 8 rozporządzenia Rzym I przez zastosowanie - w zakresie wskazanym przez art. 3 dyrektywy 96/71/WE - prawa państwa, w którym pracownik delegowany wykonuje swoje obowiązki, chyba że statut stosunku pracy (wyznaczony na podstawie art. 8 rozporządzenia Rzym I) przewiduje warunki zatrudnienia dla pracownika korzystniejsze (art. 3 ust. 7 dyrektywy $)^{17}$. Na taki sposób ingerencji wskazuje także motyw 34 . preambuły do rozporządzenia Rzym I ${ }^{18}$, uznając jednocześnie przepisy prawa państwa

${ }^{13}$ Rozporządzenie Parlamentu Europejskiego i Rady (WE) nr 593/2008 z dnia 17 czerwca 2008 r. w sprawie prawa właściwego dla zobowiązań umownych (Rzym I). Dz.Urz. UE L nr 177 z dnia 4.07.2008, s. 6-16 [dalej: rozporządzenie Rzym I].

${ }^{14}$ Konwencja rzymska z dnia 19 czerwca 1980 r. o prawie właściwym dla zobowiązań umownych. Dz.U. 2008, nr 10, poz. 57 [dalej: konwencja rzymska].

${ }_{15} \mathrm{U}$. Gru šić: The right to strike versus fundamental economic freedoms in the English courts, again: Hiding behind the „public law taboo” in private international law. „Journal of Private International Law” 2013, no. 3, s. 419; P. St one: EU Private International Law. Cheltenham-Northampton 2014, s. 356; R. Piir: Safeguarding the posted worker. A private international law perspective. „European Labour Law Journal” 2019, vol. 10, s. 103-104.

${ }_{16}$ M. Zachariasiewicz, w: „System Prawa Prywatnego”. T. 20B: Prawo prywatne międzynarodowe. Red. M. Pazdan..., s. 499. Zob. szerzej N. Wahl w opinii Rzecznika Generalnego z dnia 18.09.2014 r. w sprawie C-396/13, Sähköalojen ammattiliitto ry v. Elektrobudowa SA, pkt. 50-51. Zob. także E. Pataut: Commentaire du décret du 29 mai 2000 relatif au détachement de travailleurs effectué dans le cadre d'une prestation de services. „Revue critique de droit international privé” 2000, no 3, s. 520.

17 J. Skoczyński: Prawo właściwe w międzynarodowych stosunkach pracy pracowników delegowanych $w$ ramach świadczenia ustug (problematyka kolizyjnoprawna). „Praca i Zabezpieczenie Społeczne” 2004, nr 5, s. 37; C. Kilpatrick: Laval's regulatory conundrum. Collective standard-setting and the Court's new approach to posted workers. „European Law Review” 2009, no. 4, s. 848-849; U. Grušić: The European Private International Law of Employment. Cambridge 2015, s. 271.

18 O. Deinert: Posting of Workers to Germany - Previous Evolutions and New Influences Throughout EU Legislation Proposals. „International Journal of Comparative Labour Law and Industrial Relations" 2000, no. 3, s. 229. 
przyjmującego, regulujace warunki zatrudnienia, o których tu mowa, wprost za „wymuszajace swoje zastosowanie"19.

\section{Zmiany dyrektywy 96/71/WE wplywające na treśé stosunku pracy pracowników delegowanych}

Dyrektywa 2018/957 wprowadziła kilka istotnych modyfikacji dyrektywy 96/71/WE, majacych kluczowe znaczenie przy określaniu treści stosunku pracy pracowników delegowanych. Po pierwsze, doprecyzowują one krąg podmiotów, w stosunku do których należy stosować regulacje dyrektywy (nakładając wyraźnie taki obowiązek na przedsiębiorstwa pracy tymczasowej oraz agencje pośrednictwa pracy) ${ }^{20}$, po drugie zaś zwiększają i uszczegóławiają zakres zastosowania prawa państwa przyjmującego, kształtującego treść stosunku pracy pracowników delegowanych. Po trzecie wreszcie, dyrektywa 2018/957 rozwiewa, istniejace uprzednio, wątpliwości dotyczące okresu delegowania, w ramach którego zastosowanie miało jedynie w zakresie ograniczonym do kwestii wskazanych w art. 3 ust. 1 dyrektywy 96/71/WE prawo państwa przyjmujacego, po upływie którego w pełnym zakresie reguluje ono treść stosunku pracy. Z dniem 30 lipca 2020 r. w szerszym zakresie zastosowanie znajduje zatem aktualna lex loci laboris w odniesieniu do pracowników, którzy zostali skierowani do pracy za granicę, wykonując obowiązki na rzecz pracodawcy świadczącego tam swoje usługi.

\subsection{Zakres podmiotowy dyrektywy 96/71/WE}

Podmiotowy zakres dyrektywy 96/71/WE określony został w jej art. 1, zgodnie z którym dyrektywę stosuje się do usługodawców z państwa członkowskiego Unii Europejskiej, delegujacych pracowników do innego państwa członkowskiego w celu wykonania tam usługi ${ }^{21}$. Z kręgu pracowników, do których znajduje zastosowanie regulacja dyrektywy, wyłączono personel pływający zatrudniony w przedsiębiorstwach mary-

19 Zob. szerzej R. Piir: Safeguarding the posted worker..., s. 110-112.

20 P. Wąż: Zmiany w zakresie delegowania..., s. 10-11.

21 Dyrektywa 96/71/WE znajduje także zastosowanie w odniesieniu do usługodawców Europejskiego Obszaru Gospodarczego i Szwajcarii. 
narki handlowej (art. 1 ust. 2) ${ }^{22}$. Dyrektywa 2018/957 nie wprowadziła w opisanym powyżej zakresie zmian. Dalej bowiem obowiązuje wyłączenie podmiotowe odnoszące się do wskazanej grupy pracowników wykonujacych swoje obowiązki na statkach marynarki handlowej. Jednocześnie nowela dyrektywy 96/71/WE włączyła wprost do kręgu podmiotów, do których regulacje ochronne znajdą zastosowanie, pracowników sektora transportu drogowego. Nastapi to z dniem 2 lutego $2022 \mathrm{r}^{23}$, wraz z rozpoczęciem stosowania dyrektywy Parlamentu Europejskiego i Rady (UE) 2020/1057 z dnia 15 lipca $2020 \mathrm{r} .^{24} \mathrm{w}$ ramach tzw. pakietu mobilności ${ }^{25}$. Warto wskazać, że kwestia stosowania dyrektywy 96/71/WE do kierowców międzynarodowego transportu drogowego jest sporna i stała się przedmiotem wniosku niderlandzkiego Hoge Raad do Trybunału Sprawiedliwości Unii Europejskiej o wydanie orzeczenia w trybie prejudycjalnym ${ }^{26}$.

Przesłanka stosowania opisanego wyżej mechanizmu kolizyjnego, polegającego na konieczności sięgnięcia $\mathrm{w}$ ramach stosunku pracy (podlegającego co do zasady prawu państwa wysyłającego) do przepisów prawa państwa przyjmującego, w sferach określonych art. 3 ust. 1 dyrektywy 96/71/WE jest: a) delegowanie pracowników na własny rachunek i pod swoim kierownictwem do innego państwa członkowskiego, w ramach umowy zawartej między usługodawcą a odbiorca usług, o ile istnieje

${ }^{22}$ A. Charbonneau: Marché international du travail maritime. Un cadre juridique en formation. Aix-en-Provence 2009, s. 343; P. Wąż: Delegowanie pracowników do innego państwa celem świadczenia ustug. Warszawa 2011, s. 25; A. van Hoek, M. Houwerzijl: 'Posting' and 'Posted Workers': The Need for Clear Definitions of Two Key Concepts of the Posting of Workers Directive. In: The Cambridge Yearbook of European Legal Studies 2011-2012. Vol. 14. Eds. C. Barnard, M. Gehring, I. Solanke. Cambridge, s. 433; L. Carballo Piñeiro: International Maritime Labour Law. Berlin-Heidelberg 2015, s. 154.

${ }^{23}$ Zgodnie z art. 3 ust. 3 dyrektywy 2018/957, ma to bowiem nastapić od daty rozpoczęcia stosowania aktu ustawodawczego zmieniającego dyrektywę 2006/22/WE w odniesieniu do wymogów dotyczących egzekwowania prawa oraz ustanawiającego szczegółowe zasady w odniesieniu do dyrektywy 96/71/WE i dyrektywy 2014/67/UE dotyczace delegowania kierowców w sektorze transportu drogowego.

${ }_{24}$ Dyrektywa Parlamentu Europejskiego i Rady (UE) 2020/1057 z dnia 15 lipca 2020 r. ustanawiająca przepisy szczególne w odniesieniu do dyrektywy 96/71/WE i dyrektywy 2014/67/UE dotyczące delegowania kierowców w sektorze transportu drogowego oraz zmieniająca dyrektywę 2006/22/WE w odniesieniu do wymogów w zakresie egzekwowania przepisów oraz rozporządzenie (UE) nr 1024/2012. Dz.Urz. UE L nr 249 z dnia 31.07.2020, s. 49-65.

${ }^{25}$ P. Wą̇̇: Zmiany w zakresie delegowania..., s. 12; G. Bania: Zastosowanie prawa państwa przyjmujacego do pracownika delegowanego. „Monitor Prawa Pracy” 2019, nr 8, s. 24.

${ }^{26}$ Zob. wniosek w sprawie C-815/18, Federatie Nederlandse Vakbeweging c/a Van den Bosch Transporten BV, Van den Bosch Transporte GmbH, Silo-Tank kft. 
stosunek pracy pomiędzy delegującym a tymże pracownikiem w okresie delegowania; b) delegowanie pracowników do zakładu albo przedsiębiorstwa należącego do grupy przedsiębiorców na terytorium innego państwa członkowskiego, o ile istnieje stosunek pracy pomiędzy delegującym a tymże pracownikiem w okresie delegowania, albo wreszcie c) wynajęcie pracownika przedsiębiorstwu, użytkownikowi prowadzącemu działalność gospodarczą lub działającemu na terytorium innego państwa członkowskiego przez przedsiębiorstwo pracy tymczasowej ${ }^{27}$, lub agencję pośrednictwa pracy, o ile przez cały okres delegowania istnieje stosunek pracy pomiędzy przedsiębiorstwem pracy tymczasowej lub agencją pośrednictwa pracy a pracownikiem ${ }^{28}$.

Co istotne, w przypadku gdy pracownicy przedsiębiorstwa pracy tymczasowej lub agencji pośrednictwa pracy zostali skierowani przez przedsiębiorstwo użytkownika do świadczenia pracy w innym państwie członkowskim, to sa oni uznawani za delegowanych przez przedsiębiorstwo pracy tymczasowej lub agencję pośrednictwa pracy, z którymi pozostaja w stosunku pracy ${ }^{29}$. Na tych ostatnich spoczywaja zatem obowiazki wynikajace ze znowelizowanej dyrektywy 96/71/WE i to oni powinni dostosować się do zmienionych warunków pracy swoich pracowników. W tym téz celu dyrektywa 2018/957 nakłada na przedsiębiorstwa użytkowników powinność powiadomienia przedsiębiorstwa pracy tymczasowej albo agencji pośrednictwa pracy, z odpowiednim wyprzedzeniem, o delegowaniu takich pracowników do świadczenia pracy za granicę. Wymienione doprecyzowanie dotychczasowej regulacji ma na celu wyraźne wskazanie podmiotu odpowiedzialnego za stosowanie mechanizmu wynikającego z dyrektywy 96/71/WE oraz usprawnienie obiegu informacji do tego niezbędnych.

${ }^{27} \mathrm{Na}$ temat przedsiębiorstw pracy tymczasowej zob. szerzej D. Makowski: Zatrudnianie pracowników poprzez agencje pracy tymczasowej w świetle prawa wspólnotowego. „Praca i Zabezpieczenie Społeczne” 2003, nr 7, s. 14-15.

${ }^{28}$ P. Davies: Posted Workers: Single Market of Protection of National Labour Law System? „Common Market Law Review” 1997, no. 3, s. 576; W. Sa netra: Delegowanie pracowników do pracy w innym kraju w prawie europejskim. „Praca i Zabezpieczenie Społeczne" 1998, nr 9, s. 10-11; C. Barnard: EC Employment Law. Oxford 2006, s. 281; S. Majkowska-Szulc: Sytuacja prawna pracownika delegowanego w ramach świadczenia ustug. W: Przeptyw osób $i$ świadczenie ustug $w$ Unii Europejskiej. Nowe zjawiska i tendencje. Red. S. Biernat, S. Dudzik. Warszawa 2009, s. 251—252; P. Wąż: Projekt dyrektywy..., s. 453; G. Bania: Zastosowanie prawa państwa przyjmujacego..., s. 21.

29 S. de Carvalho: The revision of the Posting of Workers Directive..., s. 730-731; A.M. Świątkowski: Zmienione warunki zatrudnienia i wynagrodzenia pracowników delegowanych. „Europejski Przegląd Sądowy” 2019, nr 8, s. 14; P. Wąż: Zmiany w zakresie delegowania..., s. 10-11. 


\subsection{Zakres przedmiotowy dyrektywy $96 / 71 / \mathrm{WE}$}

Celem, jaki przyświecał autorom dyrektywy 96/71/WE, było wprowadzenie mechanizmu dążącego do wypośrodkowania interesów przeciwstawnych grup: usługodawców - uczestników otwartego rynku europejskiego (w związku z gwarantowana art. 56 TFUE swobodą świadczenia usług), pracowników zatrudnionych przez tych usługodawców (pod szyldem eliminacji niekorzystnego zjawiska dumpingu socjalnego ${ }^{30}$ ), jak również — przy okazji (a może przede wszystkim) — lokalnych pracodawców i ich pracowników. Konieczne stało się zatem wyraźne określenie sfer, $\mathrm{w}$ jakich powinno znaleźć zastosowanie - w odniesieniu do pracowników delegowanych - prawo państwa, w którym pracownicy ci wykonuja swoja pracę na rzecz pracodawcy świadczącego usługi poza granicami kraju, w którym skoncentrowana jest jego podstawowa działalność. Innymi słowy, wyważenie sprzecznych interesów konkurujących na wspólnym, otwartym rynku usług podmiotów wymagało określenia zakresu zastosowania aktualnej legis loci laboris $\mathrm{w}$ odniesieniu do pracowników, których stosunki pracy poddane sa prawu innego państwa (najczęściej pochodzenia usługodawcy delegującego pracowników do pracy za granicę), przy poszanowaniu zasady, że w przypadku gdy zgodnie ze statutem stosunku pracy (a więc zazwyczaj w myśl prawa państwa, w którym pracownik zwykle świadczy pracę) obowiązuja korzystniejsze dla pracownika regulacje, to zgodnie z art. 3 ust. 7 dyrektywy 96/71/WE, znajda one zastosowanie.

Zgodnie z pierwotnym brzmieniem art. 3 ust. 1 lit. a-g dyrektywy 96/71/WE, państwa członkowskie miały obowiązek zapewnić, bez względu na to, jakie prawo jest właściwe do stosunku pracy pracowników delegowanych, zastosowanie prawa państwa członkowskiego, w którym praca jest wykonywana, w zakresie obejmujaccym: a) maksymalne okresy pracy i minimalne okresy wypoczynku; b) minimalny wymiar płatnych urlopów rocznych; c) minimalne stawki płacy wraz ze stawką za nadgodziny (z wyjątkiem uzupełniających zakładowych systemów emerytalnych); d) warunki wynajmu pracowników, w szczególności przez przedsiębiorstwa zatrudnienia tymczasowego; e) zdrowie, bezpieczeństwo i higienę w miejscu pracy; f) środki ochronne stosowane w odniesieniu do warunków zatrudniania kobiet ciężarnych lub kobiet tuż po urodzeniu dziecka,

${ }^{30}$ E. Pataut: Commentaire du décret..., s. 520; P. Wąż: Dyrektywa Nr 96/71/ WE $w$ orzecznictwie Trybunału Sprawiedliwości. „Monitor Prawniczy” 2008, nr 11, s. 574; H. Collins: Social Dumping, Multi-level Governance and Private Law in Employment Relationships. In: The Involvement of EU Law in Private Law Relationships. Eds. D. Leczykiewicz, S. Weatherill. Oxford-Portland 2013, s. 237. 
a także co do dzieci i młodzieży; g) równe traktowanie kobiet i mężczyzn oraz inne postacie równouprawnienia (niedyskryminacji) ${ }^{31}$.

Dyrektywa 2018/957 wprowadziła w tym katalogu istotne zmiany. Po pierwsze, doprecyzowano budzące wątpliwości określenie „minimalne stawki płacy" 32 , zastępując je pojęciem „wynagrodzenie”; po drugie, zakres przedmiotowy dyrektywy został rozszerzony o dwa kolejne zagadnienia, dla których zastosowanie znajduje prawo państwa, w którym pracownik aktualnie świadczy pracę, tj.: h) warunki zakwaterowania pracowników, w przypadku gdy jest ono zapewniane przez pracodawcę pracownikom znajdujacym się daleko od ich normalnego miejsca pracy, oraz i) stawki dodatków lub zwrot wydatków na pokrycie kosztów podróży, wyżywienia i zakwaterowania dla pracowników znajdujących się daleko od domu z powodów zawodowych ${ }^{33}$. Dodatkowo, określenie „minimalny wymiar płatnych urlopów rocznych” zastąpiono wyrażeniem „minimalny wymiar płatnego corocznego urlopu wypoczynkowego" i dokonano innych mało istotnych korekt leksykalnych.

Na tle dotychczas obowiąującej dyrektywy 96/71/WE najwięcej wątpliwości wzbudzało precyzyjne określenie znaczenia pojęcia minimalnej stawki płacy, ustalanej na podstawie przepisów prawa państwa przyjmującego, do wypłaty której zobowiązany był pracodawca delegujący swoich

${ }^{31}$ M.-A. Moreau: Le detachment des travailleurs effectuant une prestation de services dans l'Union européenne. „Clunet” 1996, nº 4, s. 895-896; S. Knöfel: EC Legislation on Conflict of Laws: Interactions and Incompatibilities between Conflicts Rules. „The International and Comparative Law Quarterly" 1998, no. 2, s. 444; W. Sanetra: Delegowanie pracowników..., s. 13; J. Skoczyński: Prawo właściwe w międzynarodowych stosunkach pracy pracowników delegowanych w ramach świadczenia ustug (problematyka kolizyjnoprawna). „Praca i Zabezpieczenie Społeczne” 2004, nr 5, s. 38; C. Bar nard: EC Employment Law..., s. 282; M. Szpunar, M. Zachariasiewicz: Swoboda przedsiębiorczości i swoboda świadczenia ustug a działania zwiazków zawodowych — glosa do wyroku ETS z 18.12.2007 r. w sprawie C-341/05 Laval un Partneri Ltd przeciwko Svenska Byggnadsarbetarefdrbundet i inni oraz do wyroku ETS $z$ 11.12.2007 r. w sprawie C-438/05 TWF i FSU przeciwko Viking Line $i$ Viking Line Eesti. „Europejski Przegląd Sądowy” 2008, nr 7, s. 40—41; J. Karniol: Delegowanie pracowników. „Palestra” 2008, nr 5-6, s. 216; P. Wąż: Dyrektywa Nr 96/71/WE..., s. 574; S. Majkowska-Szulc: Sytuacja prawna pracownika delegowanego..., s. 252-253; P. Grzebyk: Delegowanie pracowników $w$ celu świadczenia ustug $w$ innym państwie - wybrane problemy stosowania dyrektywy 96/71. W: Prawo pracy. Refleksje i poszukiwania. Księga jubileuszowa Profesora Jerzego Wratnego. Red. G. Uścińska. Warszawa 2013, s. 408; M. Wołoszyn- Juszczyk: Perspektywy delegowania pracowników..., s. 360—361.

${ }^{32}$ Zob. R. Piir: Safeguarding the posted worker..., s. 108-110.

${ }^{33}$ R.Ş. Pătru: Discussions on new EU-wide regulations on the posting of workers. Special consideration for Directive (EU) 2018/957 amending Directive 96/71/EC on the posting of workers in the framework of the provision of services. „Juridical Tribune” 2019, vol. 9 , s. 158 . 
pracowników do pracy za granicę $e^{34}$. Mnogość regulacji krajowych tej kwestii dotyczących $\mathrm{w}$ połączeniu z niebagatelną wagą wskazanej problematyki dla stron stosunku pracy powodowały trudności interpretacyjne, które musiały być niejednokrotnie rozstrzygane przez Trybunał Sprawiedliwości Unii Europejskiej ${ }^{35}$ czy też Trybunał Europejskiego Stowarzyszenia Wolnego Handlu ${ }^{36}$. Mimo podejmowanych wysiłków, odpowiedź na pytanie, które elementy przysługującego pracownikowi wynagrodzenia moga być „zaliczone” na poczet minimalnej stawki płacy, a jakie składniki muszą być wypłacane niezależnie od pensji podstawowej, często nie była jednoznaczna ${ }^{37}$.

W znowelizowanym art. 3 ust. 1 lit. c dyrektywy 96/71/WE określenie „minimalne stawki płacy” zostało zastapione pojęciem „wynagrodzenie" $^{38}$. Na skutek tej zmiany doszło do redefiniowania obowiązku pracodawców delegujących swoich pracowników za granicę w tym za-

${ }^{34}$ N. Reich: Free Movement $v$. Social Rights in an Enlarged Union - the Laval and Viking Cases before the ECJ. „German Law Journal” 2008, no. 2, s. 142; P. Wąż: Charakterystyka transgranicznego stosunku pracy na tle dyrektywy $\mathrm{Nr}$ 96/71/WE Parlamentu Europejskiego i Rady. „Monitor Prawniczy” 2008, nr 2, s. 81; W. Kurowski: Glosa do wyroku Trybunału Sprawiedliwości Unii Europejskiej z dnia 12 lutego 2015 r. w sprawie Sähköalojen ammattiliitto ry c/a Elektrobudowa Spótka Akcyjna (C-396/13). „Problemy Prawa Prywatnego Międzynarodowego" 2019, T. 24, s. 201-202.

${ }_{35}$ Zob. wyr. TSUE z 14.04.2005 r., C-341/02, Komisja Wspólnot Europejskich v. Republice Federalnej Niemiec. Zb.Orz. 2005, s. I-02733. Przedmiotem sporu było zaliczanie przez pracodawcę na poczet minimalnego wynagrodzenia, określonego zgodnie z legis loci laboris, dodatków uzyskiwanych przez pracowników delegowanych na podstawie prawa właściwego dla umowy o pracę lub też wprost z tej umowy. Zgodnie ze wskazanym wyrokiem, na poczet minimalnego wynagrodzenia nie można było zaliczyć m.in.: świadczenia dodatkowego należnego za pracę w godzinach nadliczbowych, składek na uzupełniające zakładowe systemy emerytalne, kwot wypłaconych tytułem zwrotu wydatków faktycznie poniesionych w związku z delegowaniem. Wątpliwości wzbudzały jednak inne świadczenia, takie jak: dodatkowe wynagrodzenie roczne (tzw. trzynasta pensja), premia za „pracę brudną” czy też premia jakościowa, jak również premia za pracę w szczególnie trudnych warunkach lub niebezpieczna. Zob. też wyr. TSUE z 7.11.2013 r., C-522/12, Tevfik Isbir v. DB Services GmbH, niepubl.; wyr. TSUE z 19.06.2008 r., C-319/06, Komisja Wspólnot Europejskich v. Wielkiemu Księstwu Luksemburga. Zb.Orz. 2008, s. I-4323 oraz w szczególności wyr. TSUE z 12.02.2015 r., C-396/13, Sähköalojen ammattiliitto ry v. Elektrobudowa $S A$, niepubl.

${ }^{36}$ Zob. wyr. Tryb. ESWH z 23.01.2012 r., E-2/11, STX Norway Offshore AS v. Norwegia, niepubl.

${ }^{37}$ Zob. S. Majkowska-Szulc: Sytuacja prawna pracownika delegowanego..., s. 255-256; A. Vaitkeviciute: Minimum Wages in the Construction Sector in Finland, Sweden, Germany and Norway - A Guarantee for Workers Posted from the Baltic States? „Europäische Zeitschrift für Arbeitsrecht” 2015, H. 4, s. 414-415; W. Kurowski: Glosa do wyroku..., s. 201-208; G. Bania: Zastosowanie prawa państwa przyjmujacego..., s. 22.

${ }^{38}$ R.Ș. Pătru: Discussions on new EU-wide regulations..., s. 158-159. 
kresie; nowelizacja $\mathrm{w}$ omawianym przypadku nie miała bowiem znaczenia jedynie kosmetycznego. Pracodawcy zostali zobowiązani nie tyle do zapewniania zatrudnionym przez nich płacy minimalnej, określonej $\mathrm{w}$ państwie przyjmujacym właściwymi przepisami (czy to powszechnie obowiązującymi, czy też znajdującymi zastosowanie do określonej grupy pracowniczej), ile do dostosowania się do obowiązującej tam struktury wynagradzania pracowników ${ }^{39}$. Pojęcie „wynagrodzenia” powinno być bowiem określane zgodnie z krajowym ustawodawstwem lub praktyka danego państwa członkowskiego, do którego pracownik jest delegowany, i oznacza wszystkie elementy składowe, które są uznane za obowiązkowe na podstawie jego prawa ${ }^{40}$. Innymi słowy, delegowany do pracy $\mathrm{w}$ danym kraju powinien otrzymywać wynagrodzenie odpowiadajace płacy pracownika zatrudnionego na miejscu, wykonującego taka samą pracę. Wprowadzona dyrektywa 2018/957 zmiana spowodowała zatem rozszerzenie katalogu elementów kształtujacych wynagrodzenie pracownika delegowanego, powodując de facto zwiększenie świadczenia realnie jemu należnego. Jedynie jednym ze składników takiego „wynagrodzenia” jest przecież „minimalna stawka płacy”, uzupełniana przez różnego rodzaju dodatki (premie), związane np. z praca: w godzinach nadliczbowych, w nocy (święta), w warunkach szczególnych (szkodliwych), czy też w związku z praca na akord, a więc z praca wykraczająca poza podstawowy zakres wynikajacy $\mathrm{z}$ umowy o pracę. Tym samym zmieniona dyrektywa wpisuje się w linię orzeczniczą Trybunału Sprawiedliwości Unii Europejskiej ${ }^{41}$, dążąca do zapewnienia pracownikom delegowanym pozycji ekonomicznej zbliżonej do tej, jaka maja na stale zatrudnieni $\mathrm{w}$ danym państwie. Nie ma bowiem aksjologicznych racji przemawiajacych za odmiennym traktowaniem obu grup pracowniczych. Skoro pracownicy miejscowi otrzymuja dodatkowe wynagrodzenie za ponadstandardowa pracę, to nie sposób pozbawiać takiej premii pracowników delegowanych.

Nowelizacja dyrektywy 96/71/WE, poza kluczowa zmianą co do sposobu określenia należnego pracownikowi wynagrodzenia za pracę, po-

${ }^{39}$ A.M. Świątkowski: Zmienione warunki zatrudnienia..., s. 16; P. Wąż: Zmiany $w$ zakresie delegowania..., s. 8. Zob. także na tle wyr. TSUE z 12.02.2015 r., C-396/13, Sähköalojen ammattiliitto ry v. Elektrobudowa SA W. Kurowski: Glosa do wyroku..., s. 209.

40 Tak wprost art. 3 ust. 1 dyrektywy 96/71/WE po nowelizacji.

${ }^{41}$ Wyrok TSUE z 14.04.2005 r., C-341/02, Komisja Wspólnot Europejskich v. Republice Federalnej Niemiec. Zb.Orz. 2005, s. I-02733; wyr. TSUE z 19.06.2008 r., C-319/06, Komisja Wspólnot Europejskich v. Wielkiemu Księstwu Luksemburga. Zb.Orz. 2008, s. I-4323; wyr. TSUE z 7.11.2013 r., C-522/12, Tevfik Isbir v. DB Services GmbH, niepubl. oraz w szczególności wyr. TSUE z 12.02.2015 r., C-396/13, Sähköalojen ammattiliitto ry v. Elektrobudowa SA, niepubl. Zob. także P. Wąż: Glosa do wyroku TS z dnia 12 lutego 2015 r., C-396/13. LEX/el. 2015, pkt 3; W. Kurowski: Glosa do wyroku..., s. 201-208. 
legającą na zastapieniu wyrażenia „minimalne stawki płacy” pojęciem „wynagrodzenie”, skutkująca koniecznościa zapewnienia przez pracodawcę delegowanemu właściwej w państwie przyjmującym struktury wynagrodzenia za pracę, wprowadziła dalsze modyfikacje powodujące poszerzenie zakresu zastosowania aktualnej legis loci laboris do tej grupy zatrudnionych, wypierając $\mathrm{w}$ tym względzie regulacje statutu stosunku pracy. Określony w art. 3 ust. 1 dyrektywy 93/71/WE katalog zagadnień poddanych - co do zasady - prawu państwa, w którym pracownicy wykonuja swoje obowiązki, pozostał bowiem poszerzony o: h) warunki zakwaterowania, w przypadku gdy jest ono zapewniane przez pracodawcę pracownikom znajdującym się daleko od ich normalnego miejsca pracy, oraz i) stawki dodatków lub zwrot wydatków na pokrycie kosztów podróży, wyżywienia i zakwaterowania dla pracowników znajdujących się daleko od domu z powodów zawodowych ${ }^{42}$. Innymi słowy, w tym zakresie stosuje się prawo państwa, na terytorium którego pracownik wykonuje pracę $\mathrm{w}$ ramach oddelegowania, chyba że statut stosunku pracy przewiduje dla tych kwestii rozwiazania dla zatrudnionego korzystniejsze. Przyczyn rozszerzenia wskazanego katalogu z art. 3 ust. 1 dyrektywy 96/71/WE można doszukiwać się w motywach wyroku Trybunału Sprawiedliwości Unii Europejskiej w sprawie Sähköalojen ammattiliitto ry v. Elektrobudowa $S A^{43}$, przy wydawaniu którego sąd ten staną przed koniecznościa oceny zasadności przyznania pracownikom delegowanym świadczeń przysługujących z tych tytułów na podstawie prawa państwa przyjmującego.

Z dniem 30 lipca 2020 r. pracodawca powinien zatem zapewnić delegowanym pracownikom zakwaterowanie, jeżeli taki obowiązek wynika $\mathrm{z}$ prawa państwa przyjmującego $\mathrm{w}$ odniesieniu do zatrudnionych $\mathrm{w}$ znacznej odległości od ich normalnego miejsca pracy ${ }^{44}$. Co więcej, zgodnie z art. 3 ust. 7 dyrektywy 96/71/WE, pracownik będzie mógł domagać się tego świadczenia także wówczas, gdy powinność jego spełnienia została określona jedynie w statucie stosunku pracy. Poza tym dyrektywa 2018/957 nałożyła na pracodawców obowiązek wypłacenia pracownikom delegowanym dodatków lub zwrotu poniesionych przez nich wydatków na pokrycie kosztów podróży, wyżywienia i zakwaterowania, jeżeli w prawie państwa przyjmującego takie świadczenia przewidziano dla pracowników „znajdujących się daleko od domu z powodów zawodowych”. Co istotne, opisana powyżej powinność wypłaty dodatków lub zwrotu poniesionych wydatków dotyczy jedynie sytuacji, gdy pracownik delegowany do

${ }^{42}$ R.Ș. Pătru: Discussions on new EU-wide regulations..., s. 158.

${ }^{43}$ Zob. W. Kurowski: Glosa do wyroku..., s. 204-206.

${ }^{44}$ R.Ș. Pătru: Discussions on new EU-wide regulations..., s. 158; P. Wąż: Zmiany $w$ zakresie delegowania..., s. 7. 
pracy w innym kraju jest czasowo kierowany przez swojego pracodawcę do pracy w innym miejscu niż to, w którym normalnie w ramach delegowania świadczy pracę, co wymaga wyjazdu poza to miejsce ${ }^{45}$. Powinność wypłaty dodatków lub zwrotu wydatków na pokrycie kosztów podróży, wyżywienia i zakwaterowania, o której mowa w art. 3 ust. 1 lit. i dyrektywy 96/71/WE, dotyczy zatem jedynie podróży w ramach państwa przyjmującego lub poza jego granice, ale $\mathrm{w}$ ramach świadczenia pracy delegowanej ${ }^{46}$. Natomiast w odniesieniu do kosztów podróży, wyżywienia i zakwaterowania w związku z samym delegowaniem pracodawca dokonuje zwrotu poniesionych przez pracownika wydatków zgodnie z prawem właściwym dla danego stosunku pracy (art. 3 ust. 7 zd. 3 dyrektywy 96/71/WE) ${ }^{47}$. W takim przypadku dodatki z tytułu delegowania nie sa uznawane za część wynagrodzenia należnego pracownikowi na podstawie prawa państwa przyjmującego (w rozumieniu art. 3 ust. 1 lit. C dyrektywy). Co więcej, gdy prawo właściwe dla stosunku pracy bądź sama umowa o pracę nie określają, które elementy dodatku z tytułu delegowania sa wypłacane jako zwrot wydatków faktycznie poniesionych w związku z delegowaniem, a które są częścią wynagrodzenia, uznaje się, że cały dodatek stanowi zwrot wydatków ${ }^{48}$ (i nie jest zaliczany na poczet wynagrodzenia).

\subsection{Okres delegowania}

Trzecia wpływająca na statut stosunku pracy zmiana dyrektywy 96/71/WE, wprowadzona dyrektywa 2018/957, dotyczy okresu delegowania. Dotychczas kwestia ta nie była w sposób wyraźny unormowana ${ }^{49}$, co powodowało duże rozbieżności w stosowaniu omawianych przepisów szczególnych. To z kolei negatywnie wpływało na pozycję pracowników delegowanych, gdyż ich stosunek pracy jedynie w części normowany był przez prawo państwa przyjmującego. Tymczasem z założenia przejściowy

${ }_{45}$ Tak wprost art. 3 ust. 1 lit. i dyrektywy 96/71/WE.

${ }^{46}$ P. Wąż: Zmiany w zakresie delegowania..., s. 7.

${ }^{47}$ Zob. szerzej W. Kurowski: Glosa do wyroku..., s. 203-207. Tak też M. Szypniewski: Wspótzależności pomiędzy delegowaniem pracowników a podróża stużbowa. „Monitor Prawa Pracy” 2019, nr 9, s. 10.

${ }^{48}$ A.M. Świątkowski: Zmienione warunki zatrudnienia..., s. 17-18.

${ }_{99}$ P. Mankowski: Die Rom I-Verordnung - Änderungen im europäischen IPR für Schuldverträge. „Internationales Handelrecht” 2008, Nr. 4, s. 145; M. Wołos zy n- Ju sz czyk: Perspektywy delegowania pracowników..., s. 359-360; L. Mitrus: Charakter prawny delegowania pracowników..., s. 7; R. Piir: Safeguarding the posted worker..., s. $106-107$. 
stan wykonywania pracy w innym państwie niż to, w którym „zazwyczaj” była ona świadczona, mógł trwać latami. Co więcej, brak wyraźnej regulacji $\mathrm{w}$ tym zakresie zmuszał do dokonywania pogłębionej analizy i merytorycznego uzasadnienia każdego przypadku z osobna na podstawie różnorakich kryteriów ${ }^{50}$. Co prawda, w doktrynie zarysował się pogląd, że okres delegowania pracownika za granice nie mógł przekraczać dwóch lat ${ }^{51}$, jednakże stanowisko to znajdowało swoje uzasadnienie jedynie $\mathrm{w}$ zbieżności tego czasu $\mathrm{z}$ maksymalnym okresem podlegania przepisom z zakresu zabezpieczenia społecznego osoby delegowanej prawa państwa pochodzenia ${ }^{52}$.

Zgodnie z wprowadzonym nowela dyrektywy 96/71/WE art. 3 ust. 1a, w przypadku gdy rzeczywisty okres delegowania pracownika przekracza 12 miesięcy (w określonych przypadkach 18 miesięcy), państwo członkowskie, na terytorium którego pracownik wykonuje swoje obowiązki, ma zapewnić, bez względu na to, jakiemu prawu podlega jego stosunek pracy, poza warunkami zatrudnienia określonymi $\mathrm{w}$ enumeratywnym katalogu $\mathrm{z}$ art. 3 ust. 1 dyrektywy, stosowanie wszelkich innych majacych zastosowanie regulacji odnoszących się do stosunku pracy, zgodnie z prawem tego państwa ${ }^{53}$. Innymi słowy, po wskazanym okresie delegowania, w czasie którego jedynie w oznaczonych obszarach zastosowanie znajdowała lex loci laboris, prawo państwa przyjmującego stanie się w pełnym zakresie statutem stosunku pracy. Można zatem uznać, że z upływem wyraźnie wskazanego w art. 3 ust. 1a dyrektywy 96/71/WE okresu delegowania dochodzi do zmiany prawa właściwego dla stosunku pracy. Zważywszy bowiem na relacje pomiędzy rozporządzeniem Rzym I a dyrektywa, tak długo, jak pracownik jest delegowany do wykonywania obowiązków pracowniczych w rozumieniu dyrektywy, świadczenie pracy w innym państwie ma charakter „tymczasowego zatrudnienia”, o którym mowa w art. 8 ust. 2 zd. 2 rozporządzenia Rzym I. Nie dochodzi zatem do

${ }^{50}$ D. Martiny, in: Münchener Kommentar zum Bürgerlichen Gesetzbuch. Internationales Privatrecht I. Bd. 10. Hsrg. J. v. Hein. München 2015, s. 495-496.

${ }^{51}$ P. Mankowski: Employment Contracts Under Article 8(2) of the Rome I Regulation. In: Rome I Regulation. The Law Applicable to Contractual Obligations in Europe. Eds. F. Ferrari, S. Leible. Munich 2009, s. 187; M. Zachariasiewicz, w: „System Prawa Prywatnego". T. 20B: Prawo prywatne międzynarodowe. Red. M. Pazdan..., s. 503.

${ }^{52}$ Zgodnie bowiem z art. 12 ust. 1 rozporządzenia Parlamentu Europejskiego i Rady (WE) nr 883/2004 z dnia 29 kwietnia 2004 r. w sprawie koordynacji systemów zabezpieczenia społecznego (Dz.Urz. UE L nr 200 z dnia 7.06.2004, s. 1-49), maksymalny okres podlegania przepisom z zakresu zabezpieczenia społecznego osoby delegowanej, wynikającym z prawa państwa pochodzenia, wynosi właśnie 24 miesiące.

53 A.M. Świątkowski: Zmienione warunki zatrudnienia..., s. 13; S. de Carvalho: The revision of the Posting of Workers Directive..., s. 730; R. Piir: Safeguarding the posted worker..., s. 107; R.Ș. Pătru: Discussions on new EU-wide regulations..., s. 159. 
zmiany statutu stosunku pracy danego pracownika, choć następuje - co do zasady - jego modyfikacja w sposób określony przepisami dyrektywy. Z kolei upływ okresu „tymczasowego zatrudnienia” w państwie przyjmującym prowadzi do zmiany prawa właściwego dla stosunku pracy.

Co istotne, prawo państwa przyjmującego, które staje się po maksymalnym okresie delegowania statutem stosunku pracy, nie znajduje zastosowania - w związku z wyraźnym wyłączeniem $\mathrm{w}$ art. 3 ust. 1a dyrektywy 96/71/WE - do procedur, formalności i warunków zawierania i rozwiązywania umów o pracę, w tym klauzul o zakazie konkurencji, jak również do uzupełniających pracowniczych programów emerytalnych ${ }^{54}$. W tym zakresie stosuje się prawo dotychczas do tych kwestii właściwe.

Przepis art. 3 ust. 1a dyrektywy 96/71/WE wskazuje, że maksymalny okres delegowania wynosi 12 miesięcy. Jednakże w przypadku złożenia przez pracodawcę umotywowanego powiadomienia państwo przyjmujące przedłuża ten okres do 18 miesięcy ${ }^{55}$. Brzmienie wskazanego przepisu nie daje państwu przyjmującemu kompetencji do odmowy wydłużenia okresu delegowania $\mathrm{w}$ odniesieniu do danego pracownika; nie przewidziano $\mathrm{w}$ związku z tym także procedury uzyskiwania decyzji $\mathrm{w}$ tym zakresie. Pracodawca zatem jedynie powiadamia właściwy organ o swojej woli, przedkładajac stosowne „umotywowanie”. Takie działanie uznane zostało za wystarczające do przedłużenia okresu delegowania do 18 miesięcy ${ }^{56}$.

Autorzy dyrektywy 2018/957 podkreślają, że regulacje dotyczace delegowania pracowników do pracy w innym państwie członkowskim niż to, w którym zazwyczaj świadczą oni pracę, służą ochronie słusznych interesów pracowniczych. Jednakże z treści preambuły dyrektywy można wysnuć wniosek, że jej przepisy mają także na celu regulację rynku pracy przyjmującego państwa członkowskiego ${ }^{57}$, a zapewnienie pracownikom lepszej ochrony jest niezbędne dla zagwarantowania swobody świadczenia usług na sprawiedliwych zasadach zarówno w perspektywie krótko-, jak i długoterminowej. Wyraźne ograniczenie okresu delegowania pracowników do 12 (18) miesięcy ma zatem zapobiegać nadużywaniu praw ${ }^{58}$ gwarantowanych w Traktacie o funkcjonowaniu Unii Europejskiej ${ }^{59}$, w szczególności - jak już wspomniano - swobody świadczenia usług ${ }^{60}$.

${ }^{54}$ A.M. Świątkowski: Zmienione warunki zatrudnienia..., s. 13; P. Wąż: Zmiany $w$ zakresie delegowania..., s. 9.

${ }_{55}$ R.S.. Pătru: Discussions on new EU-wide regulations..., s. 159.

${ }^{56}$ A.M. Świątkow ski: Zmienione warunki zatrudnienia..., s. 13.

${ }_{57}$ Tak w motywie 9. preambuły dyrektywy 96/71/WE.

58 Tak wprost w motywie 10. preambuły dyrektywy 96/71/WE.

${ }^{59}$ Dz.Urz. UE C nr 83 z 2010, s. 1.

${ }^{60}$ H. Verschueren: Cross-Border Workers in the European Internal Market: Trojan Horses for Member States' Labor and Social Security Law? „International Journal of 
Dwudziestoletnia praktyka stosowania dyrektywy 96/71/WE pokazała drogi, jakimi pracodawcy delegujący swoich pracowników do pracy za granica unikają obowiązków płynących z jej treści. Jedną z nich było zastępowanie dotychczas delegowanych innymi pracownikami tego samego pracodawcy. Wówczas formalnie okres delegowania poszczególnych zatrudnionych nie wydawał się długi, a zatem brak było przesłanek do uznania, że statut ich stosunków pracy ulegał zmianie na prawo państwa przyjmującego. W celu wyeliminowania prób obchodzenia przepisów ${ }^{61}$, wskazujących już wprost dość krótkie okresy delegowania pracowników, w znowelizowanej dyrektywie 96/71/WE wskazano, że w przypadku gdy pracodawca zastępuje pracownika delegowanego inną osoba, wykonujaca to samo zadanie w tym samym miejscu, do okresu delegowania następcy należy doliczać czas świadczenia pracy w państwie przyjmującym wszystkich jego poprzedników ${ }^{62}$. Innymi słowy, w przypadku długoterminowych usług świadczonych przez przedsiębiorców w innym państwie członkowskim dla kolejnych delegowanych pracowników statut stosunku pracy ulega zmianie na prawo państwa przyjmującego już z chwilą rozpoczęcia wykonywania swoich obowiązków w tym kraju. Co istotne, wyrażenie „to samo zadanie w tym samym miejscu” należy interpretować, uwzględniając między innymi charakter usługi, która pracodawca ma wykonać, jak również rodzaj pracy świadczonej przez pracownika delegowanego oraz „adres(y)” miejsca pracy. Błędna byłaby zatem praktyka doliczania okresów wcześniejszego delegowania danego pracownika wykonującego pracę przy świadczeniu innej usługi swojego pracodawcy w tym samym państwie, zarówno dla tego samego, jak i innego usługodawcy.

\section{Zakończenie}

Delegowanie pracowników do pracy w innym państwie niż to, w którym zwykle wykonują oni swoje obowiązki pracownicze, ogniskuje w sobie kilka problemów, na różnych płaszczyznach. Poza zagadnieniami stricte społecznymi, związanymi z nawet krótkotrwała migracją ${ }^{63}$, uwagę po-

Comparative Labour Law and Industrial Relations" 2008, no. 2, s. 171-172; M. Wołoszyn-Juszczyk: Perspektywy delegowania pracowników..., s. 357-358.

${ }_{61}$ Tak w motywie 11 . preambuły dyrektywy 96/71/WE.

${ }^{62}$ A.M. Świątkowski: Zmienione warunki zatrudnienia..., s. 13; P. Wąż: Zmiany $w$ zakresie delegowania..., s. 10.

${ }^{63}$ M. Fornasier, M. Torga: The posting of workers: the perspective of the sending state. „Europäische Zeitschrift für Arbeitsrecht” 2013, Nr. 3, s. 358. 
winny zwracać także kwestie prawne i ekonomiczne, będace następstwem czasowego świadczenia pracy za granica ${ }^{64}$. Negocjacje prowadzone w okresie przygotowywania dyrektywy 2018/957 pokazały, jak duże znaczenie mają regulacje dotyczące delegowania pracowników zarówno dla zabezpieczenia słusznych praw tych ostatnich, jak i ochrony lokalnych rynków pracy i usług przed napływem usługodawców z państw, w których poziom, w szczególności wynagrodzeń, jest niższy. Analiza przepisów znowelizowanej dyrektywy 96/71/WE w zakresie, w jakim wpływają one na statut stosunku pracy, pozwala na wniosek, że pogodzenie sprzecznych interesów poszczególnych zainteresowanych - państw chroniących swój rynek wewnętrzny, usługodawców chcących w nieskrępowany sposób korzystać z traktatowej swobody świadczenia usług oraz pracowników delegowanych do pracy za granicę - jest zadaniem niezmiernie trudnym. Jednocześnie hasło przeciwdziałania negatywnym konsekwencjom dumpingu socjalnego ${ }^{65}$, przez zapewnienie stosowania do stosunków pracy pracowników delegowanych prawa gwarantującego im możliwie najwyższe świadczenia ${ }^{66}$, wykorzystywane jest często w celu ograniczenia możliwości działania usługodawców poza krajem ich pochodzenia. Koszty działalności przedsiębiorców za granicą stają się bowiem, w przypadku tak daleko idących obostrzeń, zbyt wysokie. Tym samym mechanizm kolizyjny, wpisany w sposób działania reguł wynikających z dyrektywy 96/71/WE, realizuje także te inne cele.

${ }^{64}$ M.-A. Moreau: Le detachment des travailleurs..., s. 890-891; E. Pataut: Régulation des rapports de travail en Europe et conflit de lois. In: Conflits de lois et régulation économique: l'expérience du marché intérieur. Eds. M. Audit, H. Muir Watt, E. Pataut. Paris 2008, s. 145-146.

${ }^{65}$ C. Barnard: EC Employment Law..., s. 275; N. Reich: Free Movement..., s. 126; S. Robin-Olivier, E. Pataut: Europe sociale ou Europe économique - A propos des affaires Viking et Laval. „Revue de Droit du Travail” 2008, nº 2, s. 80; P. Wąż: Dyrektywa Nr 96/71/WE..., s. 574; S. Lalanne: Détachement de travailleurs, élargissements de l'Union européenne et mondialisation du commerce des services. „Revue internationale du Travail” 2011, $\mathrm{n}^{\circ}$ 3-4, s. 235-236; M. Zachariasiewicz, w: „System Prawa Prywatnego". T. 20B: Prawo prywatne międzynarodowe. Red. M. Pazdan..., s. 498; P. Kwa siborski: Planowana rewizja dyrektywy 96/71/WE..., s. 12.

${ }_{66}$ Zob. E. Pataut: Commentaire du décret du 29 mai 2000 relatif au détachement de travailleurs effectué dans le cadre d'une prestation de services. „Revue critique de droit international privé" 2000, n⿳0 3, s. 520; Ch. Joerges, F. Rödl: Informal Politics Informal politics, formalised law and the „social deficit” of European integration: Reflections after the Judgement of the ECJ in Viking and Laval. „European Law Journal” 2009, no. 1, s. 10; U. Grušić: The European Private International Law..., s. 257; M. Zachariasiewicz, w: „System Prawa Prywatnego”. T. 20B: Prawo prywatne międzynarodowe. Red. M. Pazdan..., s. 498-499. 


\section{Bibliografia}

Bania G.: Zastosowanie prawa państwa przyjmujacego do pracownika delegowanego. „Monitor Prawa Pracy” 2019, nr 8.

Barnard C.: EC Employment Law. Oxford 2006.

Carballo Piñeiro L.: International Maritime Labour Law. Berlin-Heidelberg 2015.

Carvalho de S.: The revision of the Posting of Workers Directive and the freedom to provide services in EU: towards a dead end? „Juridical Tribune” 2018, vol. 8.

Charbonneau A.: Marché international du travail maritime. Un cadre juridique en formation. Aix-en-Provence 2009.

Collins H.: Social Dumping, Multi-level Governance and Private Law in Employment Relationships. In: The Involvement of EU Law in Private Law Relationships. Eds. D. Leczykiewicz, S. Weatherill. Oxford-Portland 2013.

Davies P.: Posted Workers: Single Market of Protection of National Labour Law System? „Common Market Law Review” 1997, no. 3.

Deinert O.: Posting of Workers to Germany - Previous Evolutions and New Influences Throughout EU Legislation Proposals. „International Journal of Comparative Labour Law and Industrial Relations" 2000, no. 3.

Fornasier M., Torga M.: The posting of workers: the perspective of the sending state. „Europäische Zeitschrift für Arbeitsrecht” 2013, Nr. 3.

Grušić U.: The European Private International Law of Employment. Cambridge 2015.

Grušić U.: The right to strike versus fundamental economic freedoms in the English courts, again: Hiding behind the „public law taboo” in private international law. „Journal of Private International Law” 2013, no. 3.

Grzebyk P.: Delegowanie pracowników $w$ celu świadczenia ustug $w$ innym państwie - wybrane problemy stosowania dyrektywy 96/71. W: Prawo pracy. Refleksje i poszukiwania. Księga jubileuszowa Profesora Jerzego Wratnego. Red. G. Uścińska. Warszawa 2013.

Hoek van A., Houwerzijl M.: 'Posting' and 'Posted Workers': The Need for Clear Definitions of Two Key Concepts of the Posting of Workers Directive. In: The Cambridge Yearbook of European Legal Studies 2011-2012. Vol. 14. Eds. C. Barnard, M. Gehring, I. Solanke. Cambridge.

Joerges Ch., Rödl F.: Informal Politics Informal politics, formalised law and the „social deficit” of European integration: Reflections after the Judgement of the ECJ in Viking and Laval. „European Law Journal” 2009, no. 1.

Karniol J.: Delegowanie pracowników. „Palestra” 2008, nr 5-6.

Kilpatrick C.: Laval's regulatory conundrum. Collective standard-setting and the Court's new approach to posted workers. „European Law Review” 2009, no. 4 . 
Knöfel S.: EC Legislation on Conflict of Laws: Interactions and Incompatibilities between Conflicts Rules. „The International and Comparative Law Quarterly" 1998, no. 2.

Kurowski W.: Glosa do wyroku Trybunału Sprawiedliwości Unii Europejskiej z dnia 12 lutego 2015 r. w sprawie Sähköalojen ammattiliitto ry c/a Elektrobudowa Spótka Akcyjna (C-396/13). „Problemy Prawa Prywatnego Międzynarodowego" 2019, T. 24.

Kwasiborski P.: Planowana rewizja dyrektywy 96/71/WE w świetle dotychczasowych uwarunkowań prawnych instytucji delegowania pracowników w Unii Europejskiej. „Europejski Przegląd Sądowy” 2016, nr 6.

Lalanne S.: Détachement de travailleurs, élargissements de l'Union européenne et mondialisation du commerce des services. „Revue internationale du Travail" 2011, n 3-4.

Majkowska-Szulc S.: Sytuacja prawna pracownika delegowanego $w$ ramach świadczenia ustug. W: Przepływ osób i świadczenie ustug w Unii Europejskiej. Nowe zjawiska i tendencje. Red. S. Biernat, S. Dudzik. Warszawa 2009.

Makowski D.: Zatrudnianie pracowników poprzez agencje pracy tymczasowej $w$ świetle prawa wspólnotowego. „Praca i Zabezpieczenie Społeczne” 2003, nr 7.

Mankowski P.: Die Rom I-Verordnung - Änderungen im europäischen IPR für Schuldverträge. „Internationales Handelrecht” 2008, Nr. 4.

Mankowski P.: Employment Contracts Under Article 8(2) of the Rome I Regulation. In: Rome I Regulation. The Law Applicable to Contractual Obligations in Europe. Eds. F. Ferrari, S. Leible. Munich 2009.

Martiny D., in: Münchener Kommentar zum Bürgerlichen Gesetzbuch. Internationales Privatrecht I. Bd. 10. Hrsg. J. v. Hein. München 2015.

Mitrus L.: Charakter prawny delegowania pracowników $w$ ramach swobody świadczenia usług w Unii Europejskiej. „Europejski Przegląd Sądowy” 2018 , nr 6.

Moreau M.-A.: Le detachment des travailleurs effectuant une prestation de services dans l'Union européenne. „Clunet” 1996, nº 4.

Pataut E.: Commentaire du décret du 29 mai 2000 relatif au détachement de travailleurs effectué dans le cadre d'une prestation de services. „Revue critique de droit international privé" $2000, \mathrm{n}^{0} 3$.

Pataut E.: Régulation des rapports de travail en Europe et conflit de lois. In: Conflits de lois et régulation économique: l'expérience du marché intérieur. Eds. M. Audit, H. Muir Watt, E. Pataut. Paris 2008.

Pătru R.Ș.: Discussions on new EU-wide regulations on the posting of workers. Special consideration for Directive (EU) 2018/957 amending Directive $96 / 71 / E C$ on the posting of workers in the framework of the provision of services. „Juridical Tribune” 2019, vol. 9.

Piir R.: Safeguarding the posted worker. A private international law perspective. „European Labour Law Journal” 2019, vol. 10. 
Reich N.: Free Movement v. Social Rights in an Enlarged Union - the Laval and Viking Cases before the ECJ. „German Law Journal” 2008, no. 2.

Robin-Olivier S., Pataut E.: Europe sociale ou Europe économique - A propos des affaires Viking et Laval. „Revue de Droit du Travail” 2008, n 2.

Sanetra W.: Delegowanie pracowników do pracy $w$ innym kraju w prawie europejskim. „Praca i Zabezpieczenie Społeczne” 1998, nr 9.

Skoczyński J.: Prawo właściwe $w$ międzynarodowych stosunkach pracy pracowników delegowanych $w$ ramach świadczenia ustug (problematyka kolizyjnoprawna). „Praca i Zabezpieczenie Społeczne” 2004, nr 5.

Stone P.: EU Private International Law. Cheltenham-Northampton 2014.

Szpunar M., Zachariasiewicz M.: Swoboda przedsiębiorczości $i$ swoboda świadczenia ustug a działania zwiazków zawodowych - glosa do wyroku ETS z 18.12.2007 r. w sprawie C-341/05 Laval un Partneri Ltd przeciwko Svenska Byggnadsarbetarefdrbundet $i$ inni oraz do wyroku ETS $z$ 11.12.2007 r. $w$ sprawie C-438/05 TWF i FSU przeciwko Viking Line $i$ Viking Line Eesti. „Europejski Przegląd Sądowy” 2008, nr 7.

Szy pniew ski M.: Współzależności pomiędzy delegowaniem pracowników a podróża stu̇̇bowa. „Monitor Prawa Pracy” 2019, nr 9.

Świątkowski A.M.: Zmienione warunki zatrudnienia i wynagrodzenia pracowników delegowanych. „Europejski Przegląd Sądowy” 2019, nr 8.

Vaitkeviciute A.: Minimum Wages in the Construction Sector in Finland, Sweden, Germany and Norway - A Guarantee for Workers Posted from the Baltic States? „Europäische Zeitschrift für Arbeitsrecht” 2015, H. 4.

Verschueren H.: Cross-Border Workers in the European Internal Market: Trojan Horses for Member States' Labor and Social Security Law? „International Journal of Comparative Labour Law and Industrial Relations” 2008, no. 2.

Wą̇̇ P.: Charakterystyka transgranicznego stosunku pracy na tle dyrektywy Nr 96/71/WE Parlamentu Europejskiego i Rady. „Monitor Prawniczy” 2008, nr 2.

Wąż P.: Delegowanie pracowników do innego państwa celem świadczenia ustug. Warszawa 2011.

Wąż P.: Dyrektywa Nr 96/71/WE w orzecznictwie Trybunału Sprawiedliwości. „Monitor Prawniczy” 2008, nr 11.

Wąż P.: Glosa do wyroku TS z dnia 12 lutego 2015 r., C-396/13. LEX/el. 2015.

Wąz P.: Projekt dyrektywy w sprawie egzekwowania dyrektywy 96/71/WE dotyczacej delegowania pracowników $w$ ramach świadczenia ustug. „Monitor Prawa Pracy” 2013, nr 9.

Wąż P.: Zmiany w zakresie delegowania pracowników do innego państwa celem świadczenia ustug od 30.7.2020 r. „Monitor Prawa Pracy” 2020, nr 10.

Wołoszyn-Juszczyk M.: Perspektywy delegowania pracowników polskich do krajów Unii Europejskiej. W: Studia z zakresu prawa pracy i polityki spotecznej. Red. A.M. Świ ittkowski. Warszawa 2014.

Zachariasiewicz M., w: „System Prawa Prywatnego”. T. 20B: Prawo prywatne międzynarodowe. Red. M. Pazdan. Warszawa 2015. 